\title{
Understanding Michael Porter: The Essential Guide to Competition and Strategy
}

Book Review

\author{
Author: Joan Magretta \\ Reviewed by: Shiva Kumar Srinivasan \\ IIPM Chennai, India \\ shiva.srinivasan@iipm.edu
}

What is the managerial understanding of strategy? That is the question which Joan Magretta sets out to answer in this lucid introduction to the work of Michael Eugene Porter. The significance of this question is related to the fact that Porter is not only an extremely rigorous thinker, but is quite prolific as well. Most readers have sampled his work and are acquainted with the technical terms of consequence, but may not have been able to put together the conceptual schema of competitive strategy as whole. Magretta's authorial intention then is to bring together the theories of 'competition' and 'strategy' in Porter's work into a cohesive argument that can serve as an introduction for those who wish to read further, or to serve as a corrective for those who might have misunderstood the significance of Porter's work. Magretta was educated at Harvard Business School, she has worked as a strategy consultant, served as Porter's editor at the Harvard Business Review, and is presently affiliated to the Institute for Strategy and Competitiveness which he heads at HBS. She is well acquainted with Porter's texts, his institutional contributions at HBS and HBR, and knows him well personally as a colleague (as evidenced not only by his cooperation with this project, but by his willingness to give her a number of sessions for the interview featured in this book in which he discusses at length both the scope of his ongoing work and some of the common misunderstandings that it has given rise to). Magretta is not attempting to summarize Porter's work as a whole, but focuses instead on those aspects that are relevant to making sense of the relationship between the terms 'competition' and 'strategy'. This book is not meant to be a comprehensive intellectual biography, but is a guide for managers who wish to actually apply its insights in the firms that they head. It is written with the firm conviction that Porter's work is not only the sine qua non for thinking about contemporary corporate strategy, but also provides the basic vocabulary for thinking sensibly about strategy in business academia.

The book is divided into two parts: the first part focuses on competition and the second on strategy. These two parts are followed by an epilogue that sets out the 'implications' of Porter's work. It also has an interview in which Porter addresses frequently asked questions along with a glossary of technical terms that he uses in his work. There are also chapter notes and sources for those who wish to read further on competition and strategy. The first part sets out the theoretical lineaments of competition by analyzing the importance of the five forces model of competition, and explains the role of competitive advantage in strategic analysis. The relationship between the construction of a value chain and its implications for P\&L are also set out. In the second part, Magretta analyzes what exactly is meant by the notion of value creation and the trade-offs that constitute strategy formulation and implementation. It also sets out the five tests of a good strategy along with a periodic reiteration of the need to have one. A firm can be said to have a strategy or to be thought of as thinking strategically only if it passes all the five tests. Understanding what these tests are by thinking through the challenges of each of these is an important part of Magretta's exposition of Porter's work. She finds that the significance of these tests is often overlooked in practice or is not even attempted in firms. This is one of those instances where she hopes her book will serve as a useful corrective for those who wish to practice the art of making strategic interventions in their firms. This book will also be a useful tool for consultants who have to make expository presentations to their clients on what exactly is the scope of their strategic recommendations, and the conditions that must be met, before their clients can determine the challenges of strategic implementation. Magretta's long years of experience as a consultant and researcher on strategy make her uniquely qualified to discuss these issues in a way that both managers and lay readers will be able to appreciate and deploy, if necessary, in their own turn. Magretta's writing strategy is not to cite the academic literature on these areas an end in itself, but to invoke as many case-based examples as deemed relevant in her own estimation in order to get her points across effectively. It might be a good idea if readers were to start with the Porter interview before moving on to the expository parts. 
Porter's apprehensions about the forms of misunderstanding that characterize the reception of his work in both academia and in firms will help the reader to differentiate between 'intuitive' notions of strategy and the forms of empirical data analysis that he usually invokes in his work. This interview will knock out the illusions that most of us no doubt share about the technical meanings attributable to a large number of Porterian terms and conceptual schemas. If a reader is able to get this far without losing his confidence, he or she will be more receptive to what Magretta has to teach him or her in this book. It won't be unfair to say that an important goal of this book is to get readers to actually read Porter, and thereby reduce the misunderstandings that his work is chronically subject to. An important instance of this misunderstanding is the ubiquitous use of the term 'best' in strategic theory and practice. Porter's argument is that being the best in a given sector does not have anything necessarily to do with being a strategic player. In fact, Porter sets out the dangers involved in attempting to be the best from a strategic point of view since it not only leads to strategic imitation (given the rapid diffusion of so-called best practices in contemporary firms), but may also lead to a zero-sum game reducing the profits and/or profitability of all the leading players in a given industry. The idea that success is synonymous with being the best is so deeply built into the human psyche that it is often wrongly attributed to Porter himself or to some dominant variant of strategic theory. Again, the notions of 'competitive strategy' and 'competitive advantage' are used as figures of speech and are not related to the actual construction of the value chain or the elements that constitute the value chain for a particular firm in specific sectoral or industrial contexts. The idea that these terms are related to problems of business economics is usually forgotten rendering the terms quite useless if what is required is a rigorous strategic analysis. Yet another example of a strategic misunderstanding is the notion that a firm must grow- no matter what. But it is simply not the case that market share is more important than profits. Or, even if that were the case in some contexts, that is not the main thrust of Porter's arguments. And, finally, Porter states categorically that the notion of competitive strategy is not to destroy rival firms, but to concentrate on the process of value creation.

The task of strategic analysis is to be able to represent and deconstruct, if necessary, the value chains in contention in a competitive scenario. Porter's work is therefore not reducible to a simplistic opposition between the 'red ocean' and the 'blue ocean' where the latter is an attempt to make the competition totally irrelevant. The differences between these approaches are based on differences of degree and not differences of kind: the hasty politicization of these approaches only leads to a compounding of theoretical errors and does not serve as a guide to strategic action in practice. These are but a few of the examples of the chronic misunderstandings that have characterized the reception of Porter's work in academia and elsewhere. The basic takeaway from both Porter's comments and those of Magretta is that many practitioners do strategy of an intuitive sort but incorporate that in a Porterian vocabulary in order to convince themselves that their analyses are rigorous in the sense that Porter and Magretta declare to be necessary. Those who understand the significance of what is happening here will realize that this book is nothing less than a full-fledged recuperation of Porter's work from those who misunderstand its significance. These sort of hermeneutic maneuvers are quite common in literary criticism, but this is the first time that I have encountered it in a strong form in business studies. The takeaway here should be obvious: reading Michael Porter is mandatory for those who wish to understand the Porterian model of competitive strategy. Reading this book is therefore not a substitute for reading Porter in the original, but an invitation to attend to the task with both seriousness and urgency for those interested in these areas. 